\title{
33. ALIPHATIC HYDROCARBONS OF A CRETACEOUS BLACK SHALE AND ITS ADJACENT GREEN CLAYSTONE FROM THE SOUTHERN ANGOLA BASIN, DEEP SEA DRILLING PROJECT LEG 751
}

\author{
S. C. Brassell, Organic Geochemistry Unit, School of Chemistry, University of Bristol, Bristol BS8 1TS, \\ United Kingdom
}

\begin{abstract}
The aliphatic hydrocarbons of a Cretaceous black shale horizon (Sample 530A-96-5, 77-82 cm) and its adjacent green claystone (Sample 530A-96-5, 72-77 cm) have been examined by gas chromatography (GC) and gas chromatography-mass spectrometry (GC-MS). In this preliminary investigation the two lithologies were not completely separated, and a unimodal series of $n$-alkane contaminants was recognized in the hydrocarbon distributions of the green claystone. The major differences between the two samples appear to be the absolute levels of aliphatic hydrocarbons and the relative abundance of $n$-alkanes. In terms of environments of deposition, it appears that the background levels of organic matter principally derived from terrestrial sources, as reflected by the green claystone, are periodically swamped by massive amounts of marine organic matter during episodes of black shale deposition.
\end{abstract}

\section{INTRODUCTION}

At Site 530 the sedimentary sequence of Coniacian to Albian age (lithologic Unit 8) consists of red and green claystones interbedded with black shales. The nature of the depositional conditions that gave rise to this variability or cyclicity in sedimentation, particularly the great variance in their organic matter contents, is of major interest. In any evaluation of the causes for large fluctuations in the organic carbon contents of a sediment sequence and the reasons for the existence of individual sediment horizons with exceptionally high amounts $(>10 \%)$ of organic matter, organic geochemical studies that assess the nature and source of the sedimentary organic matter are clearly of significance. In this chapter, results from the investigation of the extractable aliphatic hydrocarbons of a Cretaceous black shale and its adjacent green claystone horizon are presented and discussed in terms of the origin and maturity of the organic matter. A specific aim of this study was to ascertain whether the sources of the organic matter of the black shale and its adjacent green claystone, as reflected in their aliphatic hydrocarbon compositions, were similar. Differences in the sources of organic matter for the two lithologies would imply that the episodes of black shale deposition were not simply intervals during which conditions favorable for the deposition and preservation of a common input of organic matter existed, but occasions when the source, the productivity, and/or transport of organic matter changed to help produce the greatly enhanced amounts of sedimentary organic carbon found in the black shales.

\section{EXPERIMENTAL}

\section{Sampling}

The samples of black shale and green claystone were taken on board ship from the working half of the core, frozen immediately, and

\footnotetext{
${ }^{1}$ Hay, W. W., Sibuet, J.-C., et al., Init. Repts DSDP, 75: Washington (U.S. Govt. Printing Office).
}

kept in that state until laboratory work-up. Although the black shale/ green claystone boundary was sharp, visual inspection of the green claystone revealed a few small (ca. 5-10 mm) lenses of black shale within it; hence the two lithologies were not entirely differentiated.

\section{Work-up Procedures}

Prior to extraction, both samples were pulverized in a Tema disc mill (as in Comet et al., 1981), and other experimental procedures followed those previously used in our other DSDP investigations (Barnes et al., 1979; Brassell et al., 1980a, 1980c; Brassell, Gowar, Eglinton, 1980; Brassell et al., 1982) except that the extracts were not saponified. Instead the total extract was methylated $\left(\mathrm{BF}_{3} / \mathrm{MeOH}\right)$ prior to thin-layer chromatography (TLC) where carboxylic acid methyl esters eluted in the 'ketone' fraction (cf. Brassell et al., 1980a). Each lipid fraction was analyzed by gas chromatography (GC) and computerized-gas chromatography-mass spectrometry (C-GC-MS) using previously described methods (Brassell et al., 1980b, 1982). Individual compounds were characterized from a combination of their GC retention times, mass spectra, and mass fragmentographic (MF) responses by reference to literature or standard mass spectra, where possible. MF was used particularly extensively in the recognition of homologous and pseudohomologous series. This preliminary investigation was intended as a qualitative description and comparison of the hydrocarbons of the black shale and the green claystone, hence no internal standards were added to determine sample recoveries since they might swamp or be undetectable among the indigenous compounds whose concentrations were unknown.

\section{RESULTS}

Of the various lipid fractions of the two sediment samples separated by TLC this chapter focuses on that containing mainly aliphatic hydrocarbons, discussing its component distributions in qualitative rather than quantitative terms.

\section{Aliphatic Hydrocarbons}

The reconstructed ion chromatograms (RIC) of the aliphatic hydrocarbon fractions from the black shale and its adjacent green claystone are shown in Figures 1A and $2 \mathrm{~A}$, respectively. In these RIC traces the significant differences between the black shale and the green claystone are evident-namely, the greater abundance of polycyclic alkanes and alkenes in the former and the dominance of $n$-alkanes in the latter. The distributions of $n$-alkanes, branched and polycyclic alkanes and al- 

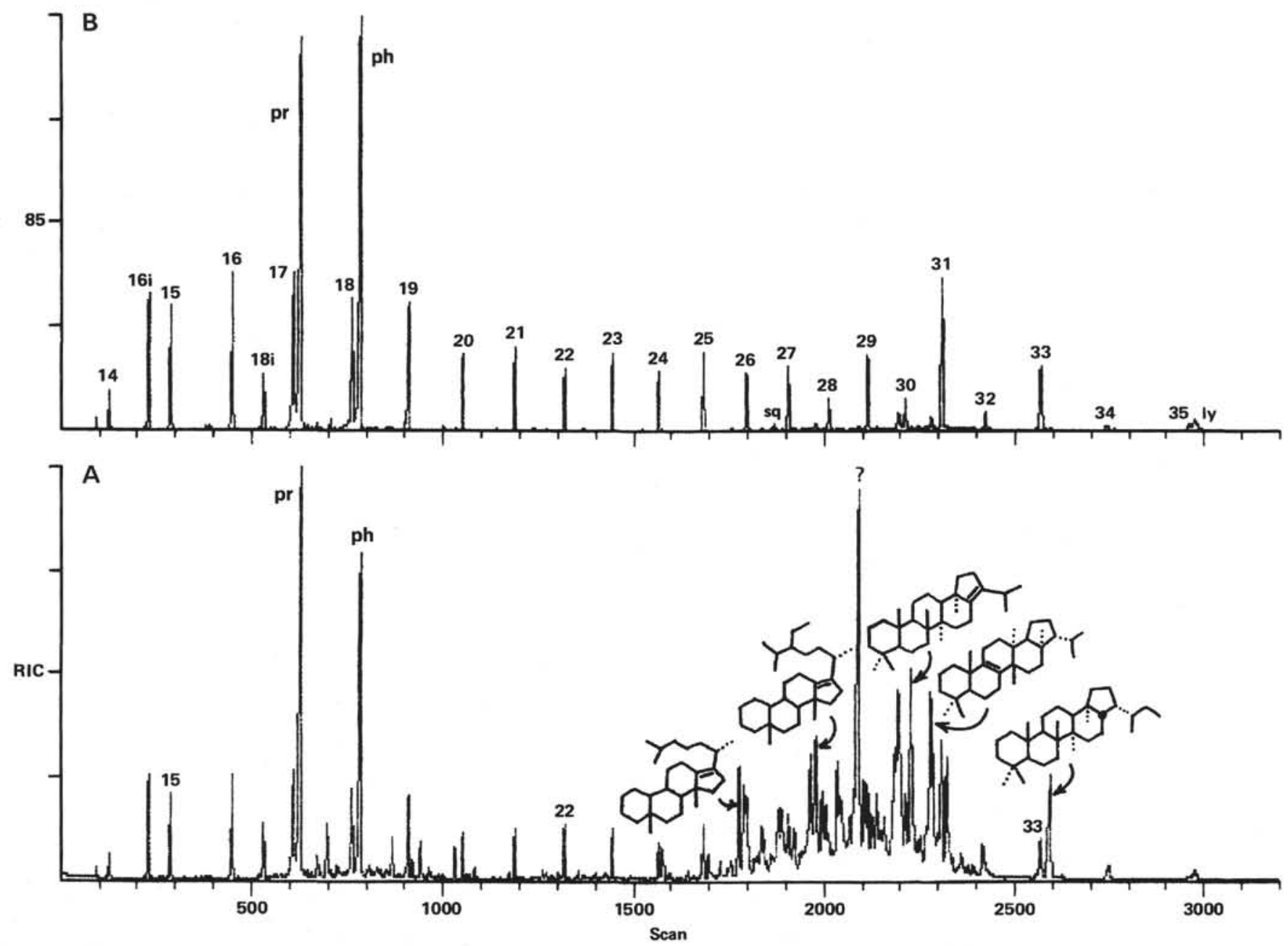

Figure 1. Reconstructed ion chromatogram (RIC; A) and mass fragmentogram of m/z 85 (B) for the black siale (Sample 96-5, 77-82 cm). Peak numbers designate $n$-alkanes, and acyclic isoprenoid alkanes are indicated as follows: 16i, 2,6,10-trimethyltridecane; 18i, 2,6,10-trimethylpentadecane; pr, pristane; ph, phytane; sq, squalane; ly, lycopane. Major diasterenes, hop-17(21)-ene, fern-8-ene, and 17 $\beta(\mathrm{H}), 21 \beta(\mathrm{H})$-homohopane are indicated. The dominant polycyclic component of the sample, denoted by ?, is a pentacyclic triterpene of unknown structure.

kenes, and selected aromatic hydrocarbons in the sediments are presented and discussed below.

\section{(i) Acyclic Components}

The distributions of $n$-alkanes and acyclic isoprenoid alkanes as characterized by MF of $\mathrm{m} / \mathrm{z} 85$, are shown in Figures 1B and 2B. The identities of the acyclic isoprenoid alkanes were confirmed from their individual mass spectra, aided by MF of m/z 183 and 197 and consideration of their GC retention times. The overall $n$-alkane distributions of the two samples differ markedly. An odd-over-even predominance (OEP) is evident in the higher homologues $\left(n-\mathrm{C}_{25}\right.$ to $\left.n-\mathrm{C}_{35}\right)$ of both sediments, but $n-\mathrm{C}_{15}$ to $n-\mathrm{C}_{19}$ homologues dominate the shorter chain-length region in the black shale, whereas a broadly Gaussian distribution of $n$-alkanes maximizing at $n-\mathrm{C}_{25}$ is present in the green claystone. Acyclic isoprenoid alkanes, notably 2,6,10-trimethyltridecane, pristane, and phytane, are prominent components of the black shale, but only minor constituents of the green claystone. Similarly, squalane and lycopane were detected in the former sample, but not in the latter. In contrast, series of iso- (2-methyl branched) and anteiso-(3-methyl branched) alkanes in the range $\mathrm{C}_{25}$ to $\mathrm{C}_{31}$ were identified in the green claystone (Fig. 2), but not in the black shale.

\section{(ii) Cyclic Components}

Steroids. The sterane compositions of the samples (Table 1) were determined from MF of $\mathrm{m} / \mathrm{z} 217$, with each component identified from its individual mass spectrum. The sterane distributions of the black shale and the green claystone, as seen from their $\mathrm{m} / \mathrm{z} 217 \mathrm{re}-$ sponses, are shown in Figures $3 \mathrm{~A}$ and 4 respectively. From the MF the black shale clearly contains a wider range of steranes than the green claystone, but it is uncertain whether this represents a genuine difference between the samples or is a reflection of detection limits.

The major steroids in both samples are diasterenes (Table 2 and Figs. 5A and 6A), which are characterized from their mass spectra and from MF of $m / z 257$. Series of 4-methyldiasterenes are also present in the sediments and were recognized from MF of $\mathrm{m} / \mathrm{z} 271$ (Table 3 and Figs. 5B and 6B). The distributions of diasterenes and 4methyldiasterenes in the two samples closely resemble each other, although their relative abundance is markedly higher in the black shale. 

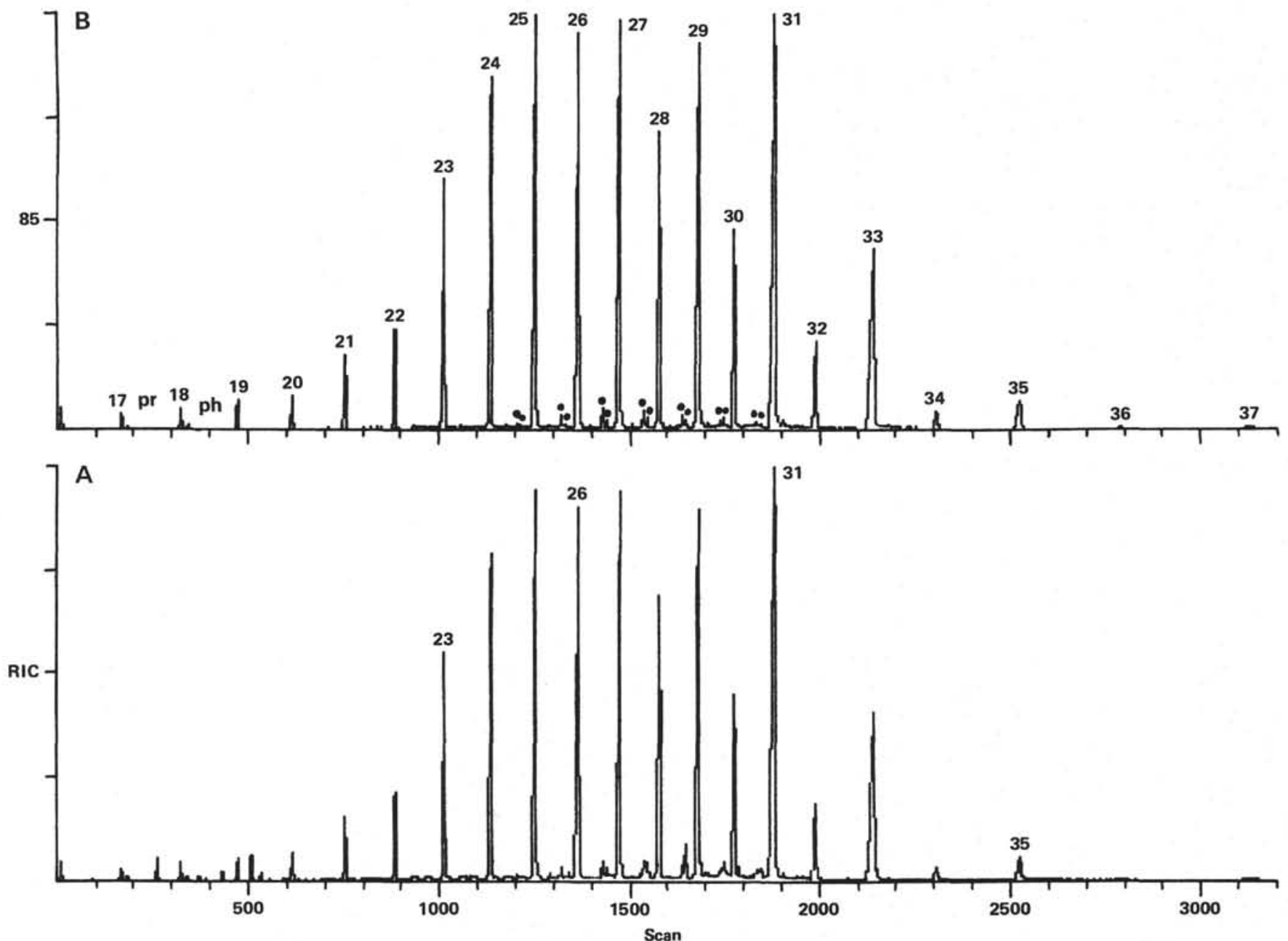

Figure 2. Reconstructed ion chromatogram (RIC; A) and mass fragmentogram of m/z 85 (B) for the green claystone (Sample $96-5,72-77 \mathrm{~cm}$ ). Peak numbers designate $n$-alkanes, and the acyclic isoprenoid alkanes pristane and phytane are denoted by $\mathrm{pr}$ and ph, respectively. Iso-(2-methyl) and anteiso- (3-methyl) branched alkanes are indicated by a closed circle.

Table 1. Sterane identifications.

\begin{tabular}{|c|c|c|}
\hline Peak $^{a}$ & Assignment & Structure $^{b}$ \\
\hline A & $5 \beta(\mathrm{H})$-cholestane & Ia \\
\hline B & $5 \alpha(\mathrm{H})$-cholestane & ІІа \\
\hline $\mathrm{C}$ & $5 \beta(\mathrm{H})$-24-methylcholestane & $\mathrm{Ib}$ \\
\hline D & $5 \alpha(\mathrm{H})$-24-methylcholestane & IIb \\
\hline E & $5 \beta(\mathrm{H})$-24-ethylcholestane & Ic \\
\hline F & $5 \alpha(\mathrm{H})$-24-ethylcholestane & IIc \\
\hline G & $5 \beta(\mathrm{H})-24$-propylcholestane ${ }^{c}$ & Id \\
\hline $\mathrm{H}$ & $5 \alpha(\mathrm{H})$-24-propylcholestane $\mathrm{e}^{\mathrm{c}}$ & IId \\
\hline
\end{tabular}

a See Figures 3A, 4.

b For compound structures see appendix to this chapter.

c Tentative assignment: compound may be 24 -isopropyl and $\mathrm{m} / \mathrm{z} 217$ response may be augmented by coeluting 4 -methylsteranes.

Only traces of sterenes, characterized from MF of $\mathrm{m} / \mathrm{z} 215$ and from their individual mass spectra, were detected in the green claystone, whereas the black shale possessed series $\left(\mathrm{C}_{27}-\mathrm{C}_{29}\right)$ of ster-4-enes and ster-5-enes, plus an additional series of earlier eluting compounds tentatively assigned as 19-normethyl-5 $\beta$-methylster-8enes (Table 4 and Fig. 3B).

Triterpenoids. Both samples contained various saturated and unsaturated triterpenoids, notably $\mathrm{C}_{27}$ and $\mathrm{C}_{29}-\mathrm{C}_{32}$ hopanes and hopenes. These compounds were identified from their GC retention times and mass spectra aided by MF of various ions, in particular $\mathrm{m} / \mathrm{z} 191$ and $\mathrm{m} / \mathrm{z} 243$ for hopanoids (Figs. 7 and 8 and Table 5) and fernenes (Figs. 9 and 10 and Table 6), respectively. In addition, both samples contain a number of other triterpenes, including the major cyclic component of the black shale (Fig. 1A), which could not be identified from their mass spectra.

Alkylcyclohexanes. The minor cyclic components of the black shale included $\mathrm{C}_{15}-\mathrm{C}_{25}$ alkylcyclohexanes (XVI, cyclohexylnonane to cyclohexylnonadecane), which were characterized from MF of $\mathrm{m} / \mathrm{z} 82$ and from their GC retention times. These compounds were not detected in the green claystone.

Tetracyclic A-ring degraded triterpenoids. Within the $n-\mathrm{C}_{21}$ to $n-\mathrm{C}_{25}$ region of the black shale aliphatic hydrocarbon fraction, there was no trace (from MF searches) 


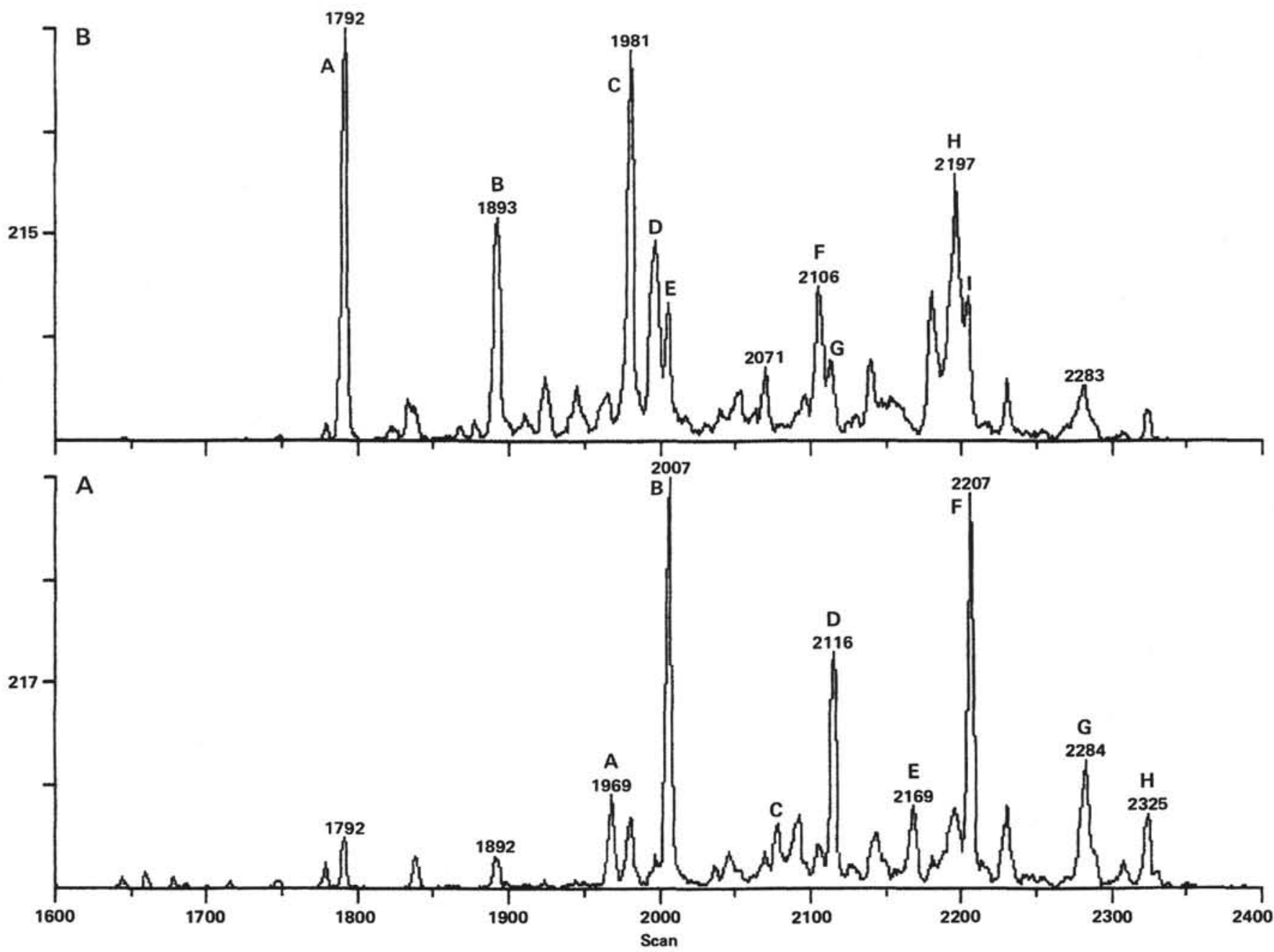

Figure 3. Partial mass fragmentograms illustrating the distributions of steranes $(\mathrm{m} / \mathrm{z} 217 ; \mathrm{A})$ and of sterenes $(\mathrm{m} / \mathrm{z} 215 ; \mathrm{B})$ in the black shale (Sample $96-5,77-82 \mathrm{~cm}$ ). The identities of the designated peaks are given in Tables 1 and 4 , respectively.

of tetracyclic A-ring degraded triterpenoids (typically $\mathrm{C}_{24}$ components; $\mathrm{cf}$. Brassell et al., 1982).

\section{Aromatic Hydrocarbons}

Aromatic Steroids. Two major series of monoaromatic steroid hydrocarbons were characterized from MF of $\mathrm{m} / \mathrm{z} 253\left(\mathrm{C}_{27}-\mathrm{C}_{29}\right.$ C-ring monoaromatics, XVII) and $239\left(\mathrm{C}_{26}-\mathrm{C}_{28} \mathrm{~A}\right.$-nor $\mathrm{C}$-ring monoaromatics?, XVIII) among the black shale hydrocarbons (Fig. 11). Trace amounts of the former series of C-ring monoaromatics were also recognized in the green claystone.

\section{Ketones and Carboxylic Acids}

The black shale also contains various acyclic functionalized lipids, including series of $n$-alkan-2-ones and $n$-alkanoic acids dominated by shorter chain homologues (characterized by MF of $\mathrm{m} / \mathrm{z} 58$ and 74, respectively) and 6,10,14-trimethylpentadecan-2-one (seen in MF of $\mathrm{m} / \mathrm{z} 58$ ). Among the cyclic components of the 'ketone' fraction obtained from TLC, the most prominent components were $\mathrm{C}_{27}-\mathrm{C}_{29} 5 \beta(\mathrm{H})$ - and $5 \alpha(\mathrm{H})$-stan-3ones (XIXa and b, respectively), $\mathrm{C}_{28}-\mathrm{C}_{30}$ 4-methylstan-3ones (XX), and various hopanoid ketones and acids (e.g., $\mathrm{Xg}$ and $\mathrm{Xh}$, respectively) recognized by $\mathrm{MF}$ of $\mathrm{m} / \mathrm{z} 231,245$, and 191 (e.g., Brassell, Glowar, Eglinton, 1980), respectively, and from their individual mass spectra. Non-hopanoid triterpenoid ketones, such as olean12-en-3-one (XXI), typically associated with higher plant inputs to sediments (Brassell et al., 1980b, 1982), were not detected in the black shale from MF of their key ions (e.g., 218, 205, 273). The components of the ketone/carboxylic acid fraction of the green claystone were present in insufficient amounts to allow their identification by GC-MS.

\section{DISCUSSION}

\section{Sample Contamination}

The $n$-alkane distribution of the green claystone can be regarded as a combination of components from two sources, one of natural origin $\left(\mathrm{C}_{25}-\mathrm{C}_{37}\right.$ with pronounced odd/even predominance-see below) and the other, a series of $\mathrm{C}_{21}$ to $\mathrm{C}_{32}$ components with a Gaussian distribution and low carbon preference index, that appears to be laboratory contamination. These contaminant alkanes have appeared sporadically in unrelated sediment and 

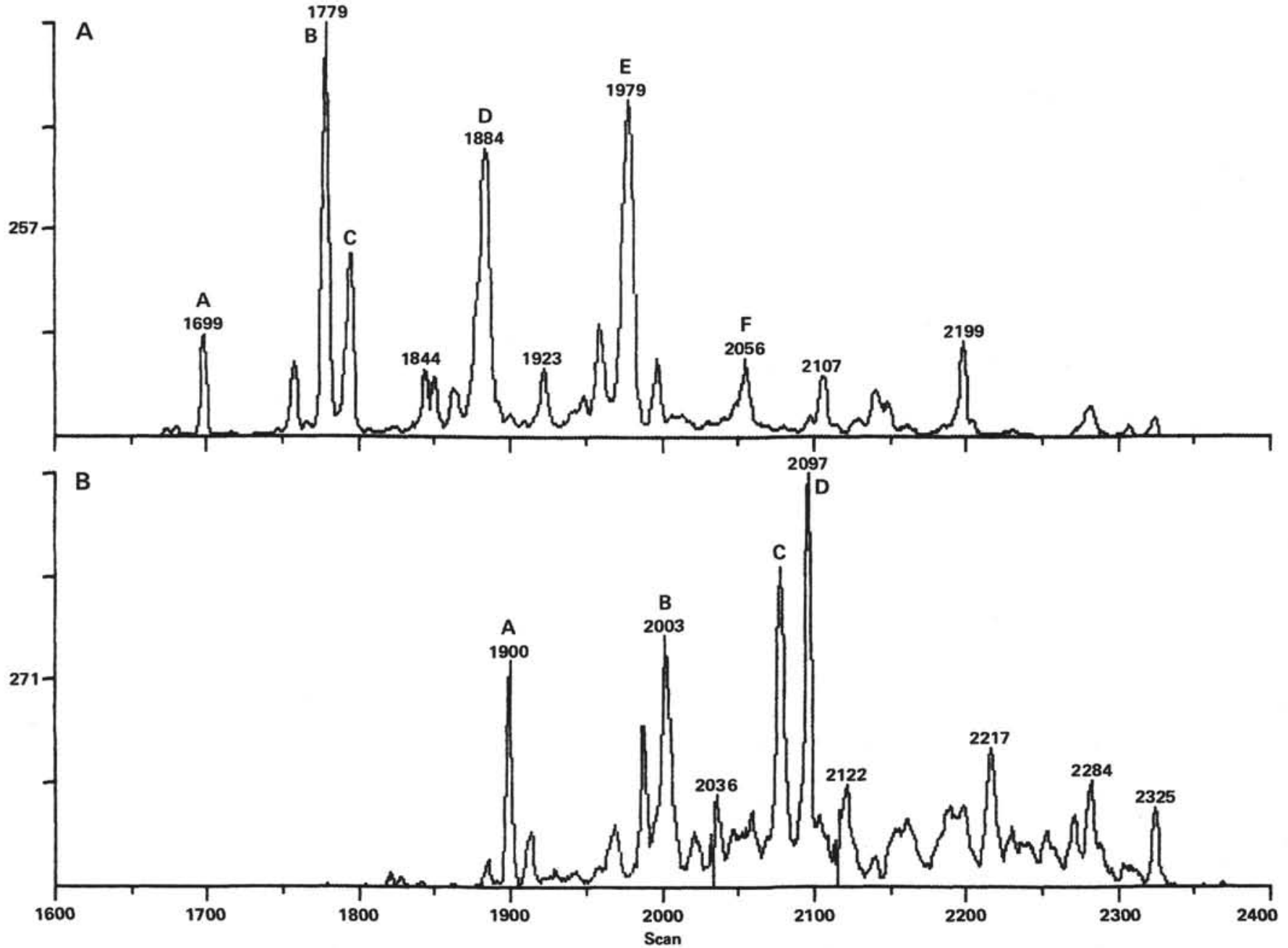

Figure 4. Partial mass fragmentogram of $\mathrm{m} / \mathrm{z} 217$ depicting the distribution of steranes in the green claystone (Sample $96-5,72-77 \mathrm{~cm})$. Peak identities are given in Table 1.

Table 2. Diasterene identifications.

\begin{tabular}{clc}
\hline Peak $^{\mathrm{a}}$ & \multicolumn{1}{c}{ Assignment } & Structure $^{\mathrm{b}}$ \\
\hline A & 20S-diacholest-13(17)-ene & IIIa \\
B & 20R-diacholest-13(17)-ene & IVa \\
C & 20S-24-methyldiacholest-13(17)-ene & IIIb \\
D $^{\mathrm{C}}$ & 20S-24-ethyldiacholest-13(17)-ene & IIIc \\
& 20R-24-methyldiacholest-13(17)-ene & IVb \\
E & 20R-24-ethyldiacholest-13(17)-ene & IVc \\
F & 20R-24-propyldiacholest-13(17)-ene & IVd
\end{tabular}

a See Figures 5A, 6A.

b For compound structures see appendix to this chapter.

components not resolved.

d Tentative assignment: compound may be 24-isopropyl.

algal samples analyzed in our laboratory, although their specific source has yet to be identified. They have only been detected, however, in samples with very low hydrocarbon contents; presumably their small amounts are swamped by the indigenous $n$-alkanes of richer samples. The other aliphatic hydrocarbons of the green claystone do not appear to be contaminants for two principal reasons; first, they are not present in other samples that contain the extraneous series of $n$-alkanes and second, they are characteristic of immature sediments and thus would not occur in any oil-based contamination.

\section{Lipid Sources}

\section{(i) Acyclic Components}

The indigenous $n$-alkane distribution of the green claystone consists of a dominant series of $\mathrm{C}_{25}$ to $\mathrm{C}_{37}$ components, with a pronounced odd/even predominance, derived from terrigenous higher plant waxes (Eglinton and Hamilton, 1967; Simoneit, 1978). The $n$-alkanes of the black shale appear to be a mixure of those components of terrestrial higher plant wax origin seen in the green claystone and an input of lower carbon number components $\left(\mathrm{C}_{14}\right.$ to $\left.\mathrm{C}_{22}\right)$ typically associated with marine organic matter (e.g., Simoneit, 1978). The distributions of $n$-alkan-2-ones and $n$-alkanoic acids are also consistent with an origin from marine sources, since the higher series members (e.g., $\mathrm{C}_{25}-\mathrm{C}_{32}$ ) typically associated with higher plant inputs (e.g., Eglinton and Hamilton, 1967; Simoneit, 1978; Brassell et al., 1980b) are not present.

The series of iso- and anteiso- alkanes in the green claystone are probably derived from terrestrial higher plants (Eglinton and Hamilton, 1967). 

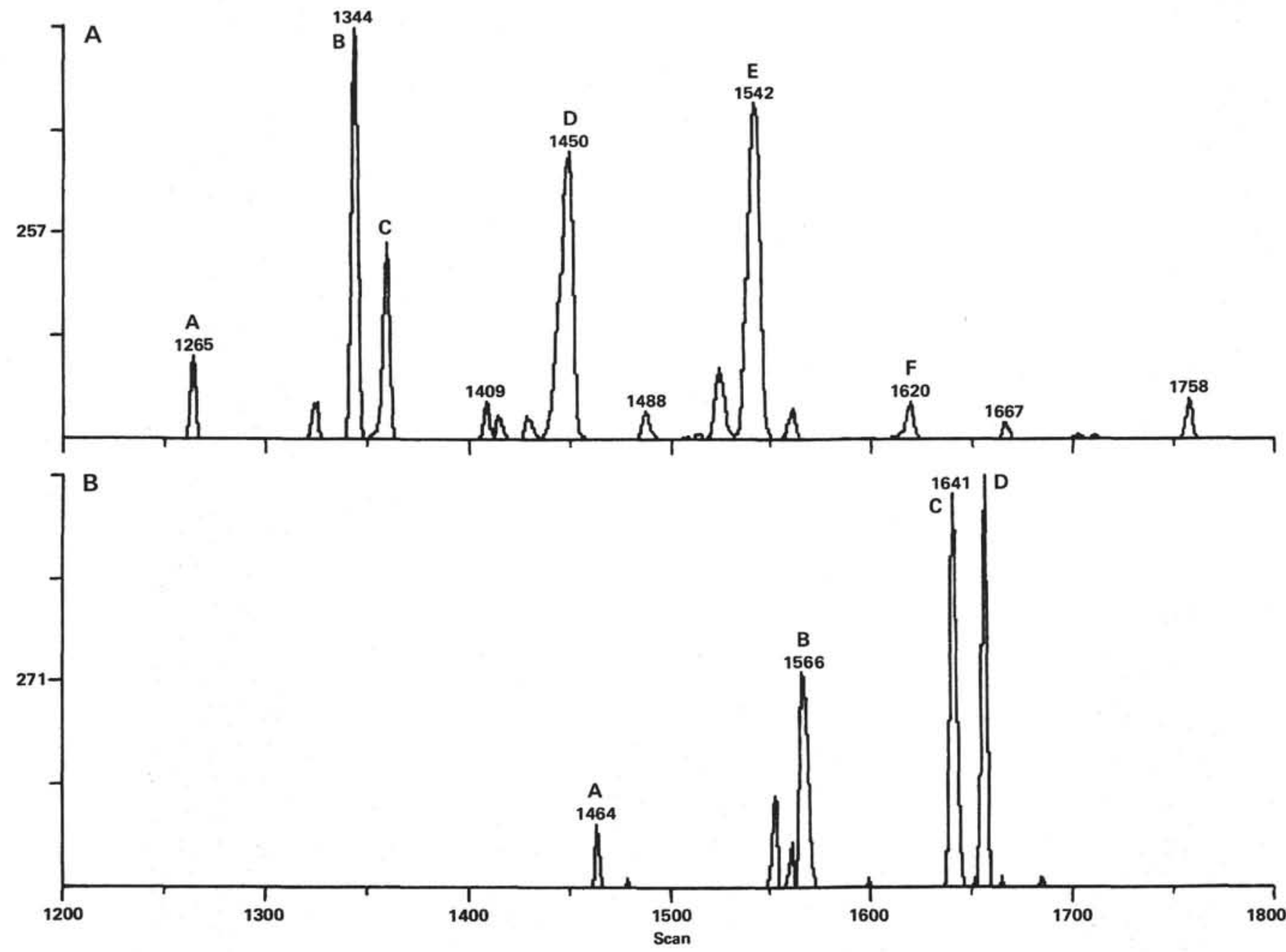

Figure 5. Partial mass fragmentograms of $\mathrm{m} / \mathrm{z} 257$ (A) and m/z 271 (B) illustrating the distributions of diasterenes and 4-methyl-diasterenes, respectively, in the black shale (Sample 96-5, 77-82 cm). The identities of designated peaks are given in Tables 2 (diasterenes) and 3 (4-methyldiasterenes).

The acyclic isoprenoid alkanes of the black shale probably originate as both direct inputs and diagenetic products from various sources, including zooplankton (a major source of pristane; Blumer et al., 1963; Avigan and Blumer, 1968), phytol derived from algal chlorophyll (e.g., Didyk et al., 1978), and methanogenic bacteria (squalane and lycopane?, Holzer et al., 1979; Brassell et al., 1981), all of which are more probably marine than terrestrial. The markedly higher relative abundances of acyclic isoprenoid alkanes (c.f., Figs. 1 and 2) in the black shale compared with those in the green claystone are, therefore, consistent with the presumption that the organic matter of the two lithologies are principally derived from marine and terrestrial sources, respectively.

\section{(ii) Cyclic Components}

The carbon number distributions of the various steroidal species in both samples are consistent with their principal origin from algal sources, since terrestrial steroidal distributions tend to be dominated by $\mathrm{C}_{29}$ components (e.g., Huang and Meinschein, 1979). The similarity of the steroidal hydrocarbon distributions of the green claystone to those of the black shale, notably the diasterenes and 4-methyldiasterenes, suggests that this inferred input of marine organic matter is common to both lithologies. In the green claystone sample, however, the amounts of these steroids are sufficiently minor that they may simply arise from the small flecks of black shale within it.

The triterpenoids of the two samples, principally hopanes, hopenes, and fernenes, show broadly similar distributions which both reflect inputs from marine algal and bacterial sources (Simoneit, 1978; Brassell et al., $1980 \mathrm{~b}, 1981,1982)$. The triterpenoids of the green claystone sample may, however, like the steroids above, be derived from the lenses of black shale within it, reflecting the incomplete separation of the two lithologies.

In both samples there is a notable absence of the triterpenoids, and also of their tetracyclic A-ring degraded derivatives that are generally assigned to origins from terrigenous higher plants. Higher plant diterpenoids (Simoneit, 1977) were also not detected in the samples. The absence of such functionalized polycyclic components suggests that the lipid evidence for inputs of terrestrial organic matter in both samples may consist mainly of more refractory components, specifically $n$-alkanes. 


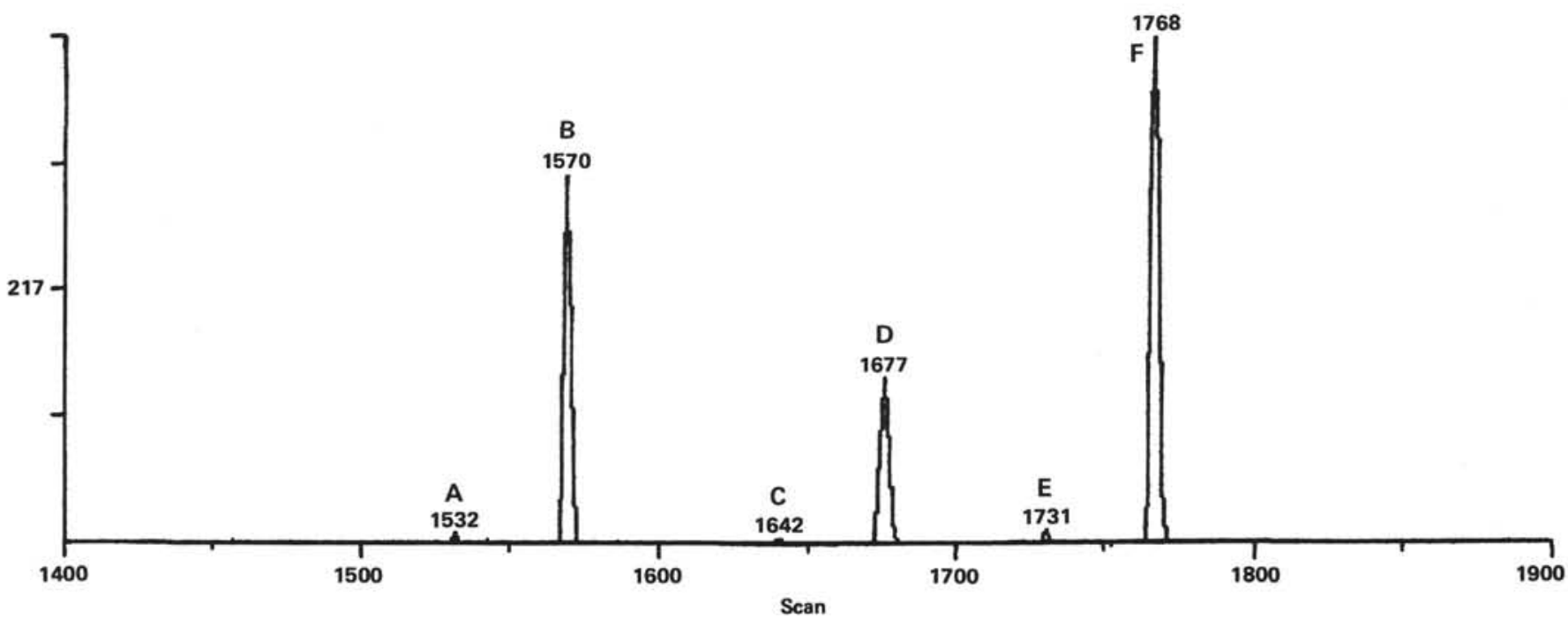

Figure 6. Partial mass fragmentograms of $\mathrm{m} / \mathrm{z} 257$ (A) and m/z 271 (B) showing the distributions of diasterenes and 4-methyl-diasterenes, respectively, in the green claystone (Sample 96-5, 72-77 cm). The identities of the designated peaks are given in Tables 2 (diasterenes) and 3 (4-methyldiasterenes).

Table 3. 4-Methyldiasterene identifications.

\begin{tabular}{clc}
\hline Peak $^{\mathrm{a}}$ & \multicolumn{1}{c}{ Assignment $^{\mathrm{b}}$} & Structure $^{\mathrm{c}}$ \\
\hline $\mathrm{A}$ & 4-methyldiacholest-13(17)-ene & $\mathrm{Va}$ \\
$\mathrm{B}$ & 4,24-methyldiacholest-13(17)-ene & $\mathrm{Vb}$ \\
C & 4-methyl-24-ethyldiacholest-13(17)-ene & $\mathrm{Vc}$ \\
$\mathrm{D}$ & 4-methyl-24-ethyldiacholest-13(17)-ene & $\mathrm{Vc}$
\end{tabular}

a See Figures 5B, 6B.

b All assignments are tentative, with the stereochemistry at C-4 and C-20 not determined and with the side chain alkylation (e.g., 24-ethyl vs. 23,24-dimethyl) also uncertain.

${ }^{\mathrm{c}}$ For compound structures see appendix to this chapter.
Table 4. Sterene identifications.

\begin{tabular}{|c|c|c|}
\hline Peak $^{\mathrm{a}}$ & Assignment & Structure ${ }^{\mathrm{b}}$ \\
\hline A & $5 \beta$-methyl-19-norcholest-8-ene ${ }^{c}$ & VIa \\
\hline B & $5 \beta, 24$-dimethyl-19-norcholest-8-ene ${ }^{c}$ & VIb \\
\hline $\mathrm{C}$ & $5 \beta$-methyl-24-ethyl-19-norcholest-8-ene $\mathrm{c}$ & VIc \\
\hline D & cholest-4-ene & VIIa \\
\hline E & cholest-5-ene & VIIIa \\
\hline F & 24-methylcholest-4-ene & VIIb \\
\hline G & 24-methylcholest-5-ene & VIIIb \\
\hline $\mathrm{H}$ & 24-ethylcholest-4-ene & VIIc \\
\hline I & 24-ethylcholest-5-ene & VIIIc \\
\hline
\end{tabular}

a See Figure 3B.

$\mathrm{b}$ For compound structures see appendix to this chapter.

c Tentative assignment based solely on mass spectral interpretation and GC retention time.

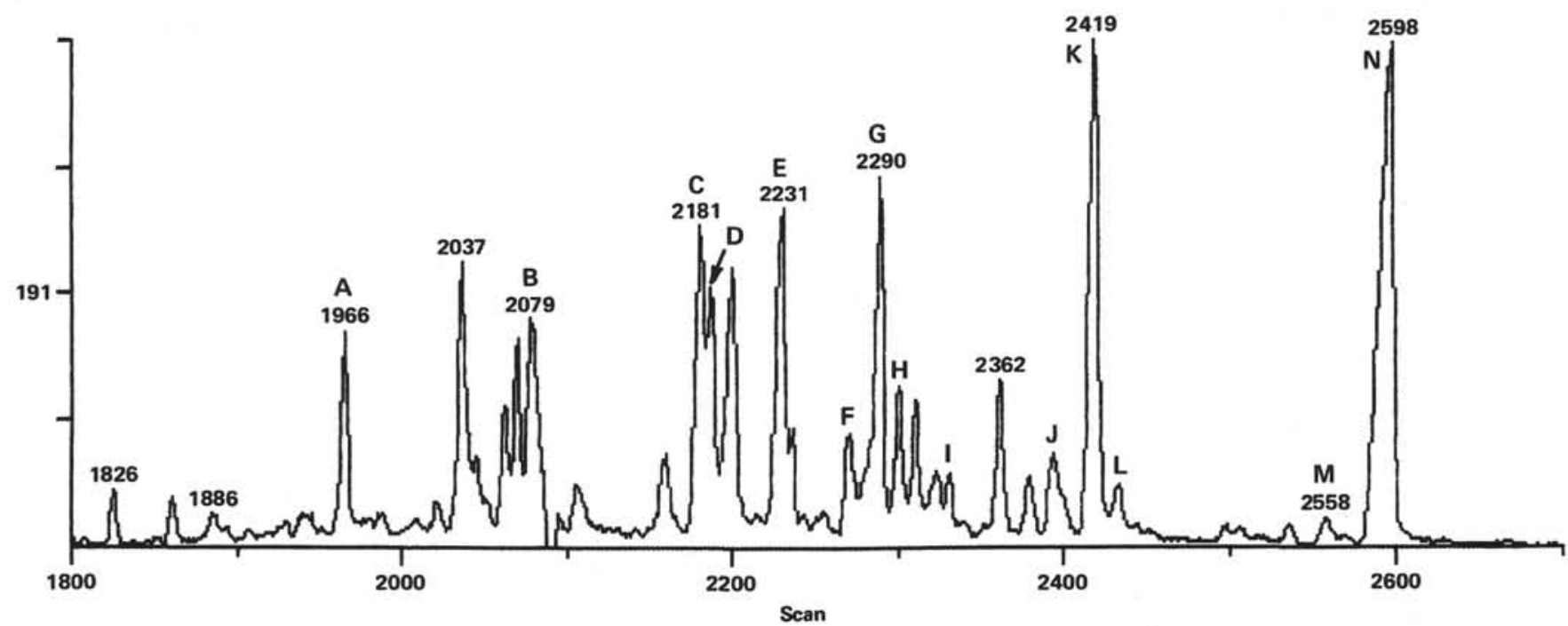

Figure 7. Partial mass fragmentogram of $\mathrm{m} / \mathrm{z} 191$, a characteristic ion in hopane and hopene mass spectra, for the black shale (Sample $96-5,77-82$ $\mathrm{cm})$. The assignments of the designated peaks are given in Table 5. This sample also contains minor amounts of $17 \beta(\mathrm{H}), 21 \beta(\mathrm{H})$-bishomohopane $(\mathrm{Xe})$ and $17 \beta(\mathrm{H}), 21 \beta(\mathrm{H})$-trishomohopane $(\mathrm{Xf})$ at higher scan numbers. 


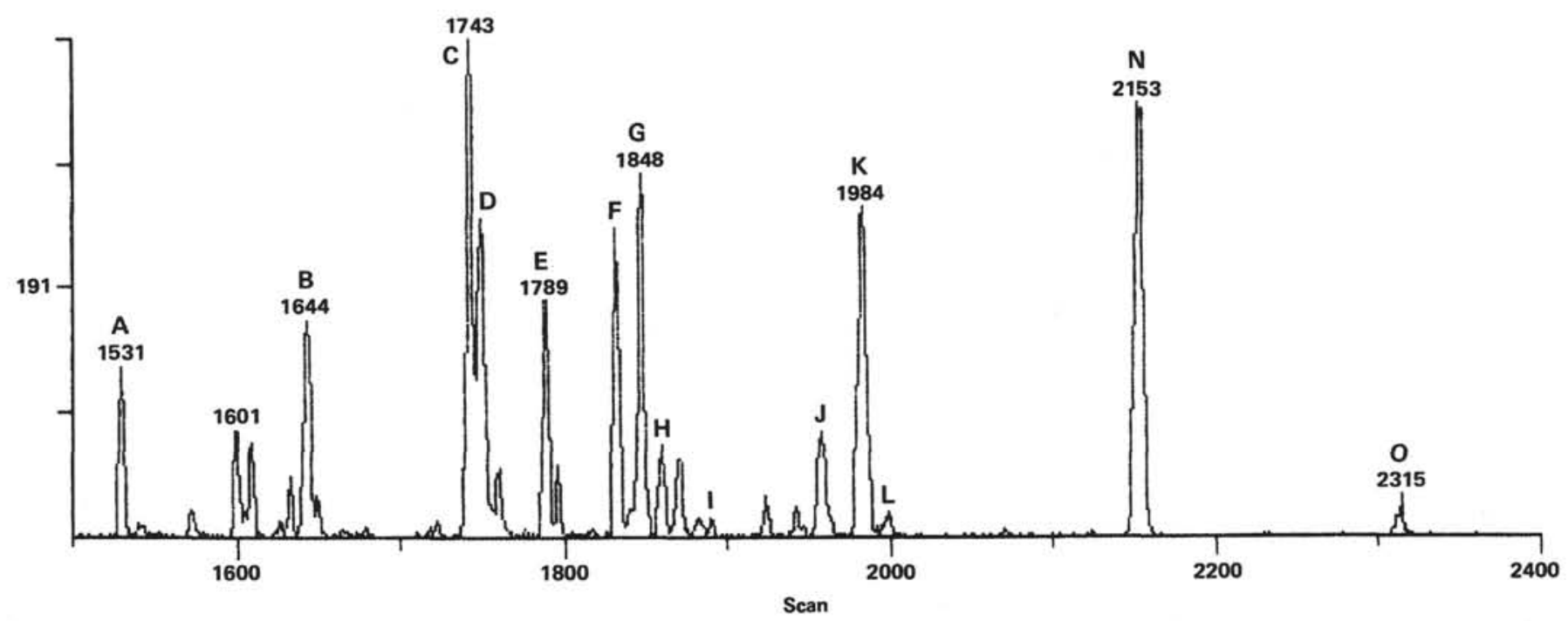

Figure 8. Partial mass fragmentogram of $\mathrm{m} / \mathrm{z} 191$ illustrating the range of hopanes and hopenes in the green claystone (Sample 96-5, 72-77 cm). The identities of the peaks denoted by letters are given in Table 5 .

Table 5. Hopanoid identifications.

\begin{tabular}{cll}
\hline Peak $^{\mathrm{a}}$ & \multicolumn{1}{c}{ Assignment } & Structure $^{\mathrm{b}}$ \\
\hline A & $22,29,30$-trisnorneohop-13(18)-ene & IXa \\
B & $17 \beta(\mathrm{H})$-22,29,30-trisnorneohopane & Xa \\
C & 30 -norneohop-13(18)-ene & IXb \\
D & 30 -norhop-17(21)-ene & XIb \\
E & hop-17(21)-ene & XIc \\
F & $17 \alpha(\mathrm{H}), 21 \beta(\mathrm{H})$-hopane & XIIc \\
G & neohop-13(18)-ene & IXc \\
H & $17 \beta(\mathrm{H}), 21 \beta(\mathrm{H})-30$-norhopane & Xb \\
I & homohop-17(21)-enec & XId \\
J & $17 \alpha(\mathrm{H}), 21 \beta(\mathrm{H})$-homohopane & XIId \\
K & $17 \beta(\mathrm{H}), 21 \beta(\mathrm{H})$-hopane & Xc \\
L & $17 \beta(\mathrm{H}), 21 \alpha(\mathrm{H})$-homohopane & XIIId \\
M & $17 \alpha(\mathrm{H}), 21 \beta(\mathrm{H})$-bishomohopane & XIIe \\
N & $17 \beta(\mathrm{H}), 21 \beta(\mathrm{H})$-homohopane & Xd \\
O & $17 \beta(\mathrm{H}), 21 \beta(\mathrm{H})$-bishomohopane & Xe \\
\hline
\end{tabular}

a See Figures 7, 8.

b For compound structures see appendix to this chapter.

c Stereochemistry at C-22 is uncertain.

The cyclohexylalkanes in the black shale may arise from cyclization and decarboxylation of alkenoic acids (Johns et al., 1966). Their carbon number distribution $\left(\mathrm{C}_{15}-\mathrm{C}_{25}\right)$ would appear, like the shorter $n$-alkanes of the black shale, to suggest an input from marine sources (cf. Simoneit, 1978).

\section{(iii) Aromatic Components}

The C-ring monoaromatic steroidal hydrocarbons are generally not indicative of the sources of organic matter in a sediment. This lack of information stems from the fact that their carbon number distributions (typically dominated by $\mathrm{C}_{28}$ components) do not match those of the steranes, sterenes, or diasterenes in the same sample (S. C. Brassell, unpublished results from many DSDP sample analyses and from other published data) and appear unrelated to those of possible precursor stenols and stanols, with the notable exception of ster5,22-dienols. A-nor C-ring monoaromatic steroidal hy- drocarbons are similarly uninformative as regards sediment inputs. The minor amounts of C-ring monoaromatic steroidal hydrocarbons detected in the green claystone may be derived, like its other steroidal and triterpenoidal components, from the small lenses of black shale within it.

\section{(iv) Summary}

The major distinction between the aliphatic hydrocarbon distributions of the black shale and the adjacent green claystone, excluding for the moment components attributed to laboratory contamination in the latter, is the relative proportion of $n$-alkanes to branched and cyclic alkanes. This difference appears to reflect the fact that the hydrocarbons of the black shale and its adjacent green claystone are principally derived from marine and terrigenous sources, respectively. In addition it seems likely that the small amounts of steranes, diasterenes, 4-methyldiasterenes, triterpenoids, and other cyclic hydrocarbons in the green claystone are associated with the small flecks of black shale present within it.

\section{Environmental Considerations}

The investigation of the lipid components of the black shale and its adjacent green claystone shows major differences in the source of their organic matter, namely in the relative proportions of $n$-alkanes principally derived from terrigenous sources versus the steroids and triterpenoids largely of marine origin. In the green claystone the amounts of $n$-alkanes greatly exceed the amounts of steroids and triterpenoids, especially as the latter may derive from the lenses of black shale within the green claystone, whereas the reverse is true for the black shale. These data suggest that the black shale horizon does not simply represent a sediment interval when enhanced preservation of organic matter occurred. Instead, it reflects a period of major sedimentation of marine organic matter that swamped the background influx of terrigenous material seen in the green claystone. 


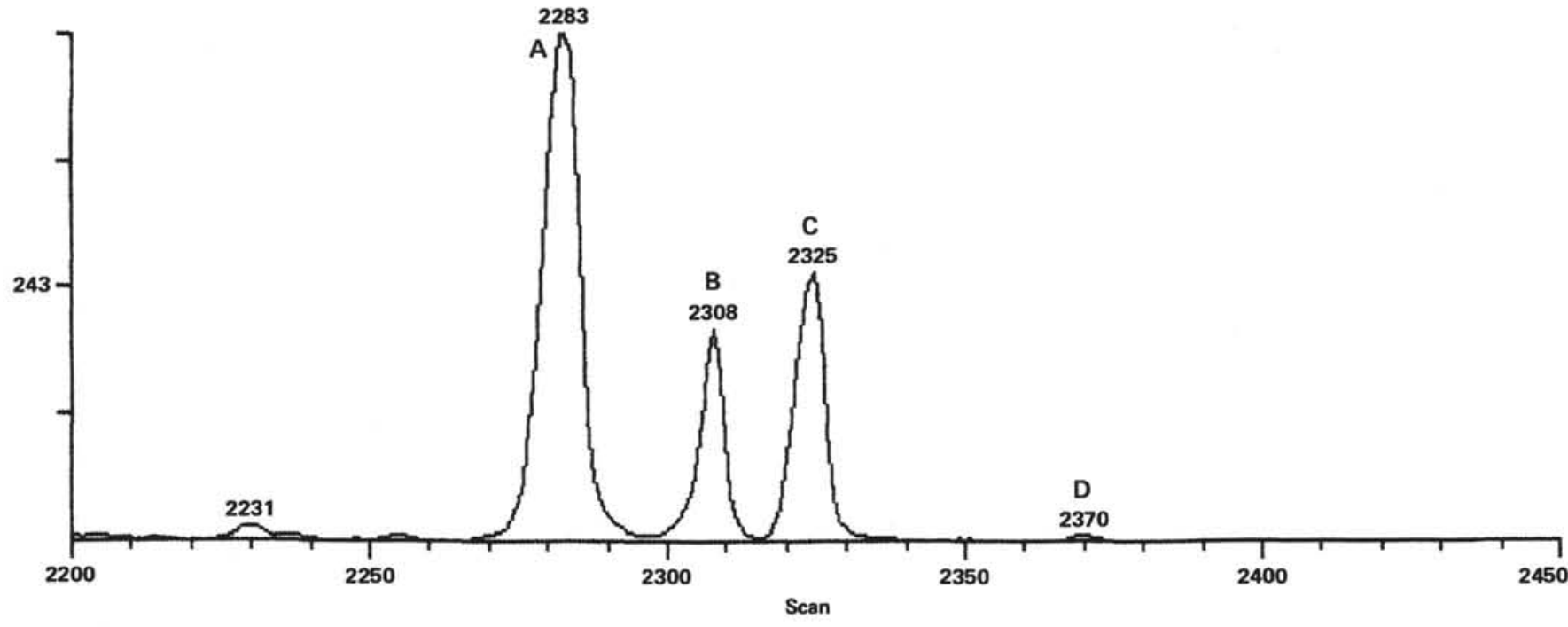

Figure 9. Partial mass fragmentogram of $\mathrm{m} / \mathrm{z} 243$ showing the distribution of fernenes in the black shale (Sample $96-5,77-82 \mathrm{~cm}$ ). The identities of the peaks denoted by letters are given in Table 6 .

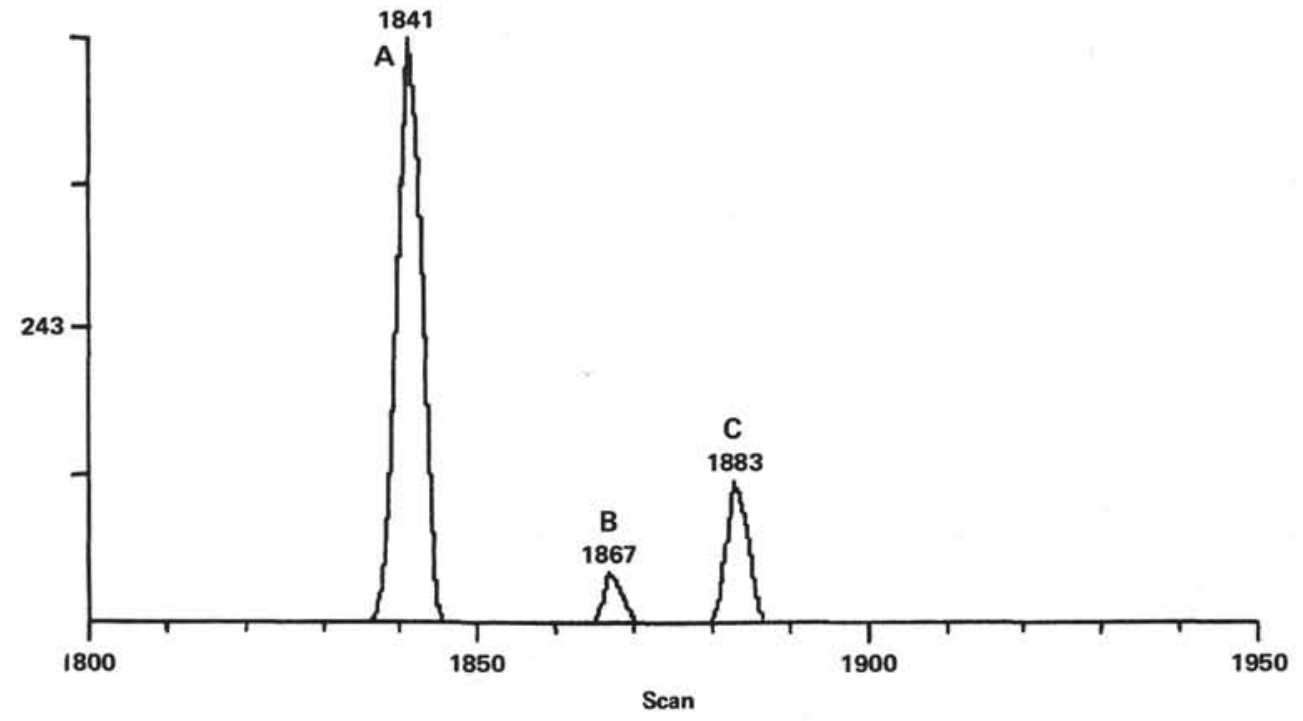

Figure 10. Partial mass fragmentogram of $\mathrm{m} / \mathrm{z} 243$ depicting the fernene distribution of the green claystone (Sample 96-5, 72-77 cm). Peak assignments are given in Table 6.

Table 6. Fernene identifications.

\begin{tabular}{clc}
\hline Peak $^{\mathrm{a}}$ & Assignment & Structure $^{\mathrm{b}}$ \\
\hline A & fern-8-ene & XIVa \\
B & fern-9(11)-ene & XIVb \\
C & Unknownc & - \\
D & fern-7-ene & XIVc \\
\hline
\end{tabular}

a See Figures 9, 10.

b For compound structures see Appendix to this chapter.

c Compound may be arbor-9(11)-ene (XV).

The evidence for terrestrial inputs to both sediments comes from the occurrence of $n$-alkane distributions characteristic of higher plant waxes. Indeed the absence of other lipid indicators of terrigenous organic matter suggests that the terrigenous lipid component in the samples may be derived from aeolian sources (Simoneit et al., 1977), where higher plant $n$-alkanes tend to dominate the lipid composition. The Cenomanian black shale sequence at Site 530 is, however, often associated with turbidites (this volume), although the influence of this mode of sedimentation on the nature and size of the terrigenous organic matter remains unclear. At Hole 416A in the Moroccan Basin the aliphatic hydrocarbons of the sequence of early Cretaceous turbidites are also dominated by higher plant wax $n$-alkanes (Brassell et al., 1980c), suggesting that this feature of the lipid distributions might be related to turbidite deposition of terrigenous organic matter.

Although no absolute quantitation of the lipid components of the two samples has been made, it is interesting to note that the concentration of the $n-C_{31}$ alkane 

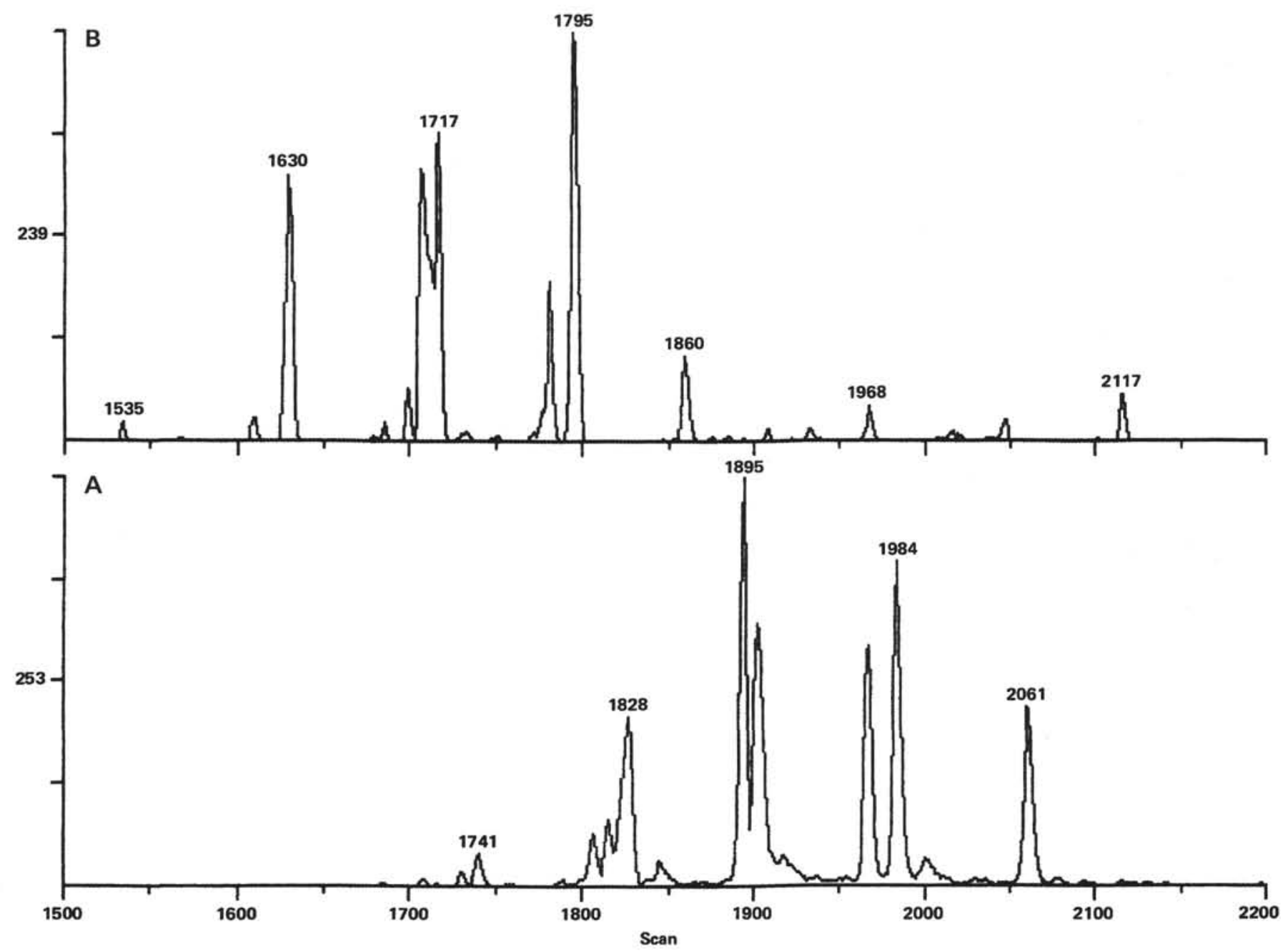

Figure 11. Partial mass fragmentograms of $\mathrm{m} / \mathrm{z} 253(\mathrm{~A})$ and $239(\mathrm{~B})$, which are characteristic ions in the mass spectra of C-ring monoaromatic steroids (XVII) and A-nor C-ring monoaromatic steroids (XVIII?), for the black shale (Section 96-5, 77-82 cm).

(the major alkane of terrestrial higher plant wax origin in the samples) is of the order of three times greater in terms of $\mathrm{g} / \mathrm{g}$ dry sediment weight in the black shale than in the green claystone. There is, therefore, an increase in the size of the terrigenous component of the black shale, relative to the green claystone, in addition to its massive influx of marine organic matter. Such higher amounts of terrestrial material may reflect the enhanced preservation of organic matter apparent in the black shale. Alternatively, considering the turbiditic nature of the sediments, the material that constitutes the black shale may derive from an area of the continental shelf margin different from that contributing to the green claystone. It is also possible that the $n$-alkanes are a remnant of a terrigenous source of organic matter rich in nutrients which gave rise to the increased marine productivity now preserved as the black shale horizon. In order to differentiate between these various explanations more detailed information concerning the precise source of the organic matter and the black shale and green claystone sediment accumulation rates is needed. It is perhaps significant, however, that the concentration of the major higher plant wax $n$-alkane $\left(n-\mathrm{C}_{31}\right)$ in $\mathrm{g} / \mathrm{g}$ sedimentary organic carbon is markedly higher in the green claystone than in the black shale (given the very large difference in their organic carbon contents), a result which can be explained as a dilution of an increased terrestrial component of organic matter in the black shale lithology by a greater influx of marine material.

The high organic carbon contents of the black shales may result from the enhanced preservation of organic matter under favorable conditions of sedimentation or may have been produced by the quantity and consequential high oxygen demand of the marine organic matter. The evidence for bioturbation in the black shale sequence (Site 530 summary, this volume) argues against a strictly anoxic environment of deposition, although the abundance of pyrite in the cores does imply subsurface anoxic conditions. It seems probable, therefore, that oxidation and reworking of organic matter occurred, but on a limited scale. The possible influence and role of turbiditic sedimentation in the generation of depositional conditions favorable to the preservation of organic matter is unclear from this limited study, although rapid burial is known to reduce the opportunity for sedimentary microbial degradation of organic matter. It is also certainly 
Table 7A. Compounds whose occurrence in the samples indicates sample immaturity. ${ }^{\mathrm{a}}$

\begin{tabular}{ll}
\hline sterenes & $n$-alkanoic acids \\
diasterenes & $n$-alkan-2-ones \\
hopenes & steroidal ketones \\
fernenes & hopanoid ketones \\
$17 \beta(\mathrm{H}), 21 \beta(\mathrm{H})$-hopanes & hopanoic acids \\
\hline
\end{tabular}

a The presence of these compounds signifies sample immaturity since none of them occur in mature sediments.

Table 7B. Lipid features indicating sample immaturity. ${ }^{b}$

Carbon preference of $n$-alkanes

Dominance of sterenes and diasterenes over steranes

Dominance of $20 \mathrm{R}, 14 \alpha(\mathrm{H}), 17 \alpha(\mathrm{H})$-steranes

Dominance of $17 \beta(\mathrm{H}), 21 \beta(\mathrm{H})$-hopanes

$\mathrm{b}_{\text {All of these features are lost with increasing sedi- }}$
ment maturity.

possible that the turbidites bring in and redeposit organic matter derived from beneath an oxygen minimum zone on the continental shelf or rise, as such material would be expected to be dominantly marine in character like that of the black shale.

\section{Maturity Considerations}

The overall distributions of lipids in both samples, excluding those components of the green claystone, specifically $n$-alkanes, believed to arise from laboratory contamination, demonstrate their thermal immaturity. The lipid features and compound occurrences that attest to the sediments' immaturity are given in Table 7A, B. In particular the prominence of functionalized lipids (alkenes, carboxylic acids, ketones) and the dominance of the biologically inherited stereochemistry in steroids and hopanoids indicate the thermal immaturity of the sediments. Such immaturity is a general feature of DSDP Cretaceous black shales from many localities (e.g., Brassell et al., 1983 and references therein), as is the dominance among their aliphatic hydrocarbons of diasterenes and hopenes.

\section{CONCLUSIONS}

The analysis of the aliphatic hydrocarbons of a black shale/green claystone lithologic pair suggests that the sedimentary sequence investigated at Site 530 consisted of a background input of higher-plant derived organic matter periodically swamped by a massive influx of marine-derived material preserved as black shale horizons. A more detailed evaluation of the sedimentary environment from such data requires a better separation of the lithologies and subsampling of specific black shale horizons. Such further studies are in progress.

\section{ACKNOWLEDGMENTS}

This study is part of projects supported by the Natural Environment Research Council (GR3/2951 and GR3/3758 to Prof. G. Eglinton and Dr. J. R. Maxwell) who are thanked for financial support and C-GC-MS facilities. I am grateful to Geoff Eglinton, James Maxwell,
Neil Lamb, and Phil Meyers for valuable discussions and to Ann Gowar for help with GC-MS analyses. I also thank Fred Prahl and Phil Meyers for their reviews of this manuscript.

\section{REFERENCES}

Avigan, J., and Blumer, M., 1968. On the origin of pristane in marine organisms. J. Lipid Res., 9:350-352.

Barnes, P. J., Brassell, S. C., Comet, P. A., Eglinton, G., McEvoy, J., et al., 1979. Preliminary lipid analyses of core sections 18, 24, and 30 from Hole 402A. In Montadert, L., Roberts, D. G., et al., Init. Repts. DSDP, 48: Washington (U.S. Govt. Printing Office), 965-976.

Blumer, M., Mullin, M. M., and Thomas, D. W., 1963. Pristane in zooplankton. Science, 140:974.

Brassell, S. C., Comet, P. A., Eglinton, G., Isaacson, P. J., and McEvoy, J., 1980a. Preliminary lipid analyses of Sections 440A-7-6, $440 \mathrm{~B}-3-5,440 \mathrm{~B}-8-4,440 \mathrm{~B}-68-2$, and 436-11-4; Legs 56 and 57, Deep Sea Drilling Project. In Scientific Party, Init. Repts. $D S D P, 56,57$, Pt. 2: Washington (U.S. Govt. Printing Office), $1367-1390$.

Brassell, S. C., Comet, P. A., Eglinton, G., Isaacson, P. J., McEvoy, J., Maxwell, J. R., Thomson, I. D., Tibbette, P. J. C., and Volkman, J. K., 1980b. The origin and fate of lipids in the Japan Trench. In Douglas, A. G., and Maxwell, J. R. (Eds.), Advances in Organic Geochemistry 1979: Oxford (Pergamon Press), pp. 375-392.

Brassell, S. C., Comet, P. A., Eglinton, G., McEvoy, J., Maxwell, J. R., et al., 1980c. Preliminary lipid analyses of Cores 14, 18, and 28 from Deep Sea Drilling Project Hole 416A. In Lancelot, Y., Winterer, E. L., et al., Init. Repts. DSDP, 50: Washington (U.S. Govt. Printing Office), 647-664.

Brassell, S. C., Gowar, A. P., and Eglinton, G., 1980. Computerized gas chromatography-mass spectromatry in analyses of sediments from the Deep Sea Drilling Project. In Douglas, A. G., and Maxwell, J. R. (Eds.), Advances in Organic Geochemistry 1979: Oxford (Pergamon Press), pp. 421-426.

Brassell, S. C., Wardroper, A. M. K., Thomson, I. D., et al., 1981. Specific acyclic isoprenoids as biological markers of methanogenic bacteria in marine sediments. Nature, 290:693-696.

Brassell, S. C., Eglinton, G., and Maxwell, J. R., 1982. Preliminary lipid analyses of two Quaternary sediments from the Middle America Trench, Southern Mexico transect, Deep Sea Drilling Project Leg 66. In Watkins, J. S., Moore, J. C., et al., Init. Repts. DSDP, 66: Washington (U.S. Govt. Printing Office), 557-580.

Brassell, S. C., Howell, V. J., Gowar, A. P., et al., 1983. Lipid geochemistry of Cretaceous sediments recovered by the Deep Sea Drilling Project. In Bjory, M., et al. (Eds.), Advances in Organic Geochemistry 1981: London (Wiley and Sons), pp. 477-484.

Comet, P. A., McEvoy, J., Brassell, S. C., Eglinton, G., Maxwell, J. R., et al., 1981. Lipids of an Upper Albian limestone, Deep Sea Drilling Project Site 465, Section 465-38-3. In Thiede, J., Vallier, T. L., et al., Init. Repts. DSDP, 62: Washington (U.S. Govt. Printing Office), 923-937.

Didyk, B. M., Simoneit, B. R. T., Brassell, S. C., et al., 1978. Organic geochemical indicators of palaeoenvironmental conditions of sedimentation. Nature, 272:216-222.

Eglinton, G., and Hamilton, R. J., 1967. Leaf epicuticular waxes. Science, 156:1322-1335.

Holzer, G., Oro, J., and Tornabene, T. G., 1979. Gas chromatographic mass spectrometric analysis of neutral lipids from methanogenic and thermoacidophilic bacteria. J. Chromatog., 186:795-809.

Huang, W. Y., and Meinschein, W. G., 1979. Sterols as ecological indicators. Geochim. Cosmochim. Acta, 43:739-745.

Johns, R. B., Belsky, T., McCarthy, E. D., et al., 1966. The organic geochemistry of ancient sediments, Part II. Geochim. Cosmochim. Acta, 30:1191-1222.

Simoneit, B. R. T., 1977. Diterpenoid compounds and other lipids in deep-sea sediments and their geochemical significance. Geochim. Cosmochim. Acta, 41:463-476. 1978. The organic chemistry of marine sediments. In Riley, J. P., and Chester, R. (Eds.), Chemical Oceanography, 7: London (Academic Press), 233-311.

Simoneit, B. R. T., Chester, R., and Eglinton, G. 1977. Biogenic lipids in particulates from the lower atmosphere over the eastern Atlantic. Nature, 267:682-685. 
S. C. BRASSELL

APPENDIX

Compound Structures

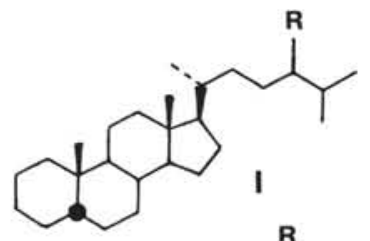<smiles>[R]C(CC[C@H](C)C1=C2CCC3C4CCCC[C@]4(C)CC[C@@H]3[C@@]2(C)CC1)C(C)C</smiles>

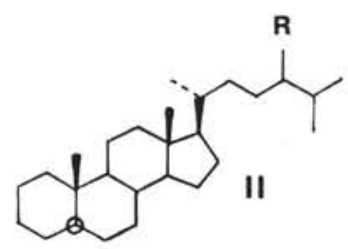

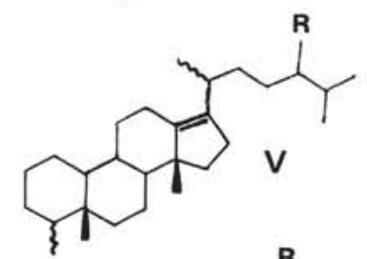<smiles>[R]C(CC[C@@H](C)[C@H]1CCC2C3CC=C4CCCCC[C@]4(C)C3CC[C@]21C)C(C)C</smiles><smiles>[R]C(CC[C@@H](C)C1=C2CC[C@H]3[C@@H]4CCCC[C@]4(C)CC[C@H]3[C@]2(C)C1)C(C)C</smiles><smiles>[R]C(CCC(C)C1CCC2=C3CC[C@]4(C)CCCCC4[C@@]3(C)CCC21C)C(C)C(C)C</smiles><smiles></smiles>

$$
{ }_{a^{H}}^{{ }^{H}} \overbrace{}^{M e}
$$<smiles>[Y]C1=CC=C2C1=CCC1C2(C)CCC2C1(C)CCC1C(C)(C)CCC[C@@]12C</smiles>

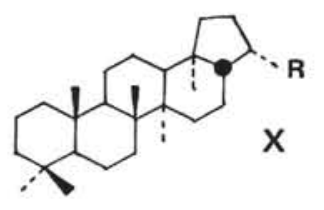

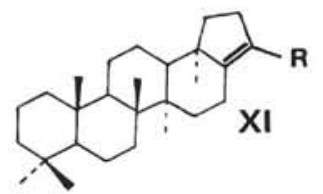

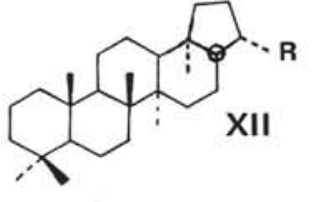

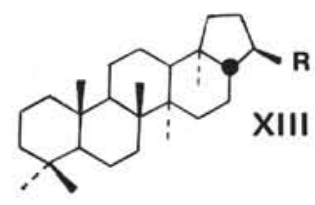

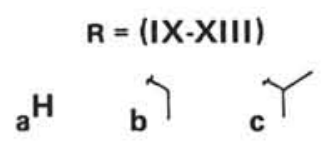<smiles>CC(C)C1CCC2C1CC[C@@]1(C)C3CCC4C(C)(C)CCCC4(C)C3CCC21C</smiles><smiles>CCCCC(C)C(C)CCC(C)C(C)CCCC</smiles><smiles>CC(C)CCC(C)CC(C)O</smiles><smiles>CC(C)CCC(=O)O</smiles>

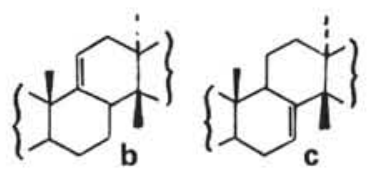<smiles>[Y][Y4]=[W]</smiles><smiles>[R]CCCCCCCCCCC1CCCCC1</smiles><smiles>[Y4]CC[C@]1(C(C)CCC([R])C(C)C)CCc2c1ccc1c2CC[C@@H]2CCCC[C@@]12C</smiles><smiles>[Y4][CH][C@H](C)[C@@]1(C)CCc2c1ccc1c2CC[C@H]2CCC[C@]12C</smiles>

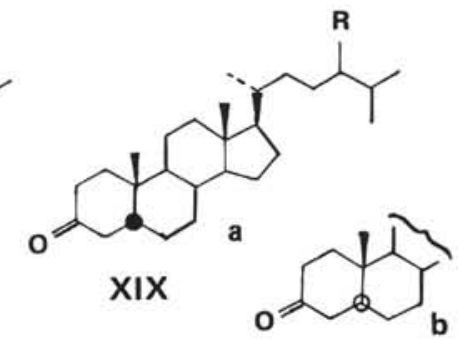

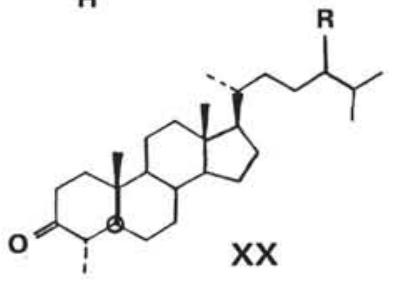

$R=(X V I I-X X)$

$\mathrm{H}, \mathrm{Me}, \mathrm{Et}$

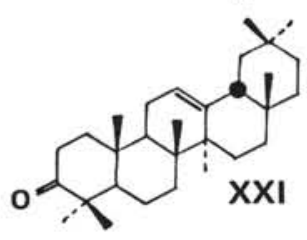

